\title{
NURSES' EXPERIENCE OF DEALING WITH PATIENTS' AGGRESSIVE BEHAVIOUR IN PSYCHIATRIC EMERGENCY WARD OF HOSPITAL IN SOUTH SULAWESI
}

\author{
Hasnah $^{1}$, Hapsah $^{1}$, Silvia Malasari ${ }^{1}$, Ariyanti Saleh ${ }^{1}$, Akbar Harisa $^{1}$ \\ ${ }^{1}$ Program Studi Ilmu Keperawatan, Fakultas Keperawatan, Universitas Hasanuddin, Makassar \\ Email: hasnah_evhy@yahoo.com
}

\begin{abstract}
Introduction: The high level of risk emergency psychiatry nurse becomes the target of aggressive behavior in patients both physically and psychologically, providing a special experience for nurses. Positive and negative impacts felt more likely a psychological effect on the nurse. Objective: Identifying the experiences of nurses dealing with patient of aggressive behavior in Emergency Psychiatric of Rumah Sakit Khusus Daerah Provinsi Sulawesi Selatan. Methods: The phenomenological approach to decision informants using purposive sampling with the informant as much as 9 informants who have experienced aggressive behavior from patients. Results: There were 7 themes obtained by the feelings of nurses with aggressive behavior patients, nurses experienced different kinds of aggressive behavior, nurses identified about the causes of the patient's aggressive behavior, nurse found some signs of the patient while being aggressive, nurses perceived impact of agresive behavior after getting the incident of it, the way nurses treated patients aggressive behavior, and nurses found obstacle to overcome aggressive behavior's patient. The positive experience of nurses in dealing with patient of aggressive behavior was nurse know the proper ways, causes and signs of the patient while being aggressive so the nurse was able to anticipate the action will be carried out. On the other hand the negative experience felt by the nurse due to the impacts of the aggressive behavior patients. Conclusions and: The experience felt by nurses in dealing with patients in Psychiatric Emergency Unit of Rumah Sakit Khusus Daerah Provinsi Sulawesi Selatan there were positive and negative. Therefore, we need a way to reduce aggressive behavior and provide management training for nurses in dealing with aggressive behavior in order to keep patients safely.
\end{abstract}

Keywords: experience, nurses, aggressive behavior.

\section{PENDAHULUAN}

Masalah kesehatan mental merupakan salah satu masalah yang harus diperhatikan walaupun dianggap tidak menyebabkan kematian secara langsung, akan tetapi dapat berpengaruh pada ketidakmampuan seseorang dalam berperilaku yang dapat menghambat kelangsungan hidupnya. Gangguan kesehatan mental merupakan suatu kondisi yang mempengaruhi proses pikir, perasaan atau suasana hati seseorang, yang dapat menyebabkan fungsi kemampuan untuk berhubungan dengan orang lain terganggu (National Alliance on Mental Illness, 2016).
Setiap tahun, penderita gangguan kesehatan mental terus bertambah. WHO memperkirakan saat ini lebih dari 450 juta penduduk di seluruh dunia mengalami gangguan mental, dan 8 diantara 10 penderita gangguan mental tersebut tidak menerima perawatan (Kementerian Kesehatan Republik Indonesia, 2013).

Unit Gawat Darurat jiwa merupakan ruangan yang menyediakan penanganan awal bagi pasien dengan gangguan kesehatan mental. Ruangan ini adalah tempat pertama yang pasien tempati pada saat diantar ke rumah sakit jiwa sehingga tingkat perilaku agresif pasien tinggi di ruangan ini. 
Gangguan mental emosi yang dialami sebagian besar pasien di rumah sakit jiwa salah satunya adalah perilaku agresif. Perilaku agresif merupakan perilaku mengancam atau melukai seseorang baik itu berupa perkataan, pukulan, atau pun dengan senjata, sebagai suatu bentuk tindakan kesengajaan untuk menghukum, dan biasanya seseorang yang berperilaku agresif juga pendendam (Warren, 1990 dalam Townsend, 2012).

Berdasarkan hasil penelitian yang dilakukan oleh Foster, Bowers, \& Nijman (2007) tentang Aggressive behaviour on acute psychiatric wards: prevalence, severity and management didapatkan bahwa dari 254 peristiwa agresi yang tercatat, sebanyak $57,1 \%$ perawat yang menjadi target dalam perilaku agresif tersebut. Anderson \& West (2011) dalam penelitiannya tentang Violence against Mental Health Professionals: When the Treater Becomes the Victim mengemukakan bahwa petugas kesehatan mental beresiko tinggi mengalami kekerasan ditangan pasien, dan diantara petugas kesehatan mental lain, perawat merupakan risiko paling tinggi yang mengalami kekerasan. Penelitian yang dilakukan oleh Arnetz \& Arnetz (2001); Kindy, Petersen, \& Parkhurst (2006) menunjukkan bahwa perasaan sedih, marah, rasa takut pada saat bekerja, merupakan dampak jangka panjang yang dialami perawat atas tindakan yang dialami. Akibatnya, waktu untuk memberikan asuhan keperawatan dan tanggung jawab perawat terhadap pasien lebih sedikit, sehingga akan berujung pada rendahnya kualitas kepedulian terhadap pasien, dan keinginan perawat untuk meninggalkan profesi perawat dan memilih pekerjaan lain.
Berdasarkan fenomena tersebut, maka tujuan utama dari penelitian ini adalah untuk mengidentifikasi pengalaman perawat dalam menghadapi pasien dengan perilaku agresif di UGD Jiwa Rumah Sakit Khusus Daerah Provinsi Sulawesi Selatan.

\section{METODE}

Peneltian ini menggunakan metode penelitian kualitatif dengan pendekatan

fenomenologi. Fenomenologi merupakan suatu metode penelitan yang kritis dan menggali fenomena yang ada secara sistematis. Hal-hal yang dikaji adalah deskripsi mengenai bagaimana pengalaman orang lain dan apa maknanya bagi mereka (Saryono \& Anggraeni, 2013).

\section{HASIL}

Data hasil wawancara dengan 9 orang informan di analisis berdasarkan content analysis. Hasil analisa data akan disajikan dalam bentuk tabel yang meliputi distribusi karakteristik informan, dan tabel analisis tema. Hasil penelitian sebagai berikut: karakteristik responden (tabel 1), perasaan perawat menghadapi pasien perilaku agresif (tabel 2), perawat mengalami berbagai jenis perilaku agresif (tabel 3), identifikasi perawat tentang faktor penyebab pasien berperilaku agresif (tabel 4), tanda-tanda pasien ketika sedang agresif menurut perawat (tabel 5), dampak yang dirasakan perawat setelah kejadian agresif (tabel 6), cara perawat dalam menangani pasien perilaku agresif (tabel 7), kendala perawat dalam menghadapi pasien perilaku agresif (tabel 8). 


\begin{tabular}{ccccc}
\hline Kode Informan & Usia & $\begin{array}{c}\text { Jenis } \\
\text { Kelamin }\end{array}$ & $\begin{array}{c}\text { Pendidikan } \\
\text { Terakhir }\end{array}$ & Lama Kerja \\
\hline I1 & 32 tahun & Perempuan & D3 & 6 tahun \\
I2 & 45 tahun & Laki-laki & D3 & 20 tahun \\
I3 & 42 tahun & Perempuan & D3 & 16 tahun \\
I4 & 30 tahun & Perempuan & D3 & 5 tahun \\
I5 & 32 tahun & Laki-laki & D3 & 6 tahun \\
I6 & 36 tahun & Perempuan & D3 & 10 tahun \\
I7 & 49 tahun & Laki-laki & D3 & 24 tahun \\
I8 & 37 tahun & Llaki-laki & S1 & 15 tahun \\
I9 & 39 tahun & Perempuan & S1 Ns & 7 tahun \\
\hline
\end{tabular}

Tabel 1. Karakteristik informan

\begin{tabular}{|c|c|c|}
\hline Kata Kunci & Kategori & Tema \\
\hline $\begin{array}{l}\text {....pengalaman saya menghadapi pasien } \\
\text { agresif, ya.. biasa-biasaji(I1) } \\
\text {...biasaji tidak ada rasa takut. Kan sudah } \\
\text { lamami(I2) } \\
\text {....biasa-biasaji, namanya juga orang sakit } \\
\text { jiwa(I7) } \\
\text {....kan sudah risiko pekerjaanmi toh, } \\
\text { apalagi kita kan tau yang kita hadapi itu } \\
\text { orang gila, jadi yang saya rasakan itu biasa- } \\
\text { biasaji(I8) }\end{array}$ & $\begin{array}{c}\text { Perasaan } \\
\text { positif }\end{array}$ & \multirow{2}{*}{$\begin{array}{c}\text { Perasaan perawat } \\
\text { menghadapi pasien } \\
\text { perilaku agresif }\end{array}$} \\
\hline $\begin{array}{l}\text {...pertamanya sih takut, tapi kalau lama- } \\
\text { lama sih sudah enda'(I2) } \\
\text {...menakutkan, mengerikan, } \\
\text { mengkhawatirkan.. takutnya yah.. pasien } \\
\text { menciderai petugas(I3) } \\
\text {... amajing.. dumba'-dumba', takut(I4) } \\
\text {...takutki iya... orang mengamuk(I5) } \\
\text {...ya takut(I6) } \\
\text {...kalau rasa takut ada sih(I7) } \\
\text {... awalnyaji itu takut, dan inikan sudah } \\
\text { risikonya profesita toh(I9) }\end{array}$ & $\begin{array}{c}\text { Perasaan } \\
\text { negatif }\end{array}$ & \\
\hline
\end{tabular}

Tabel 2. Pengalaman perawat menghadapi pasien perilaku agresif 


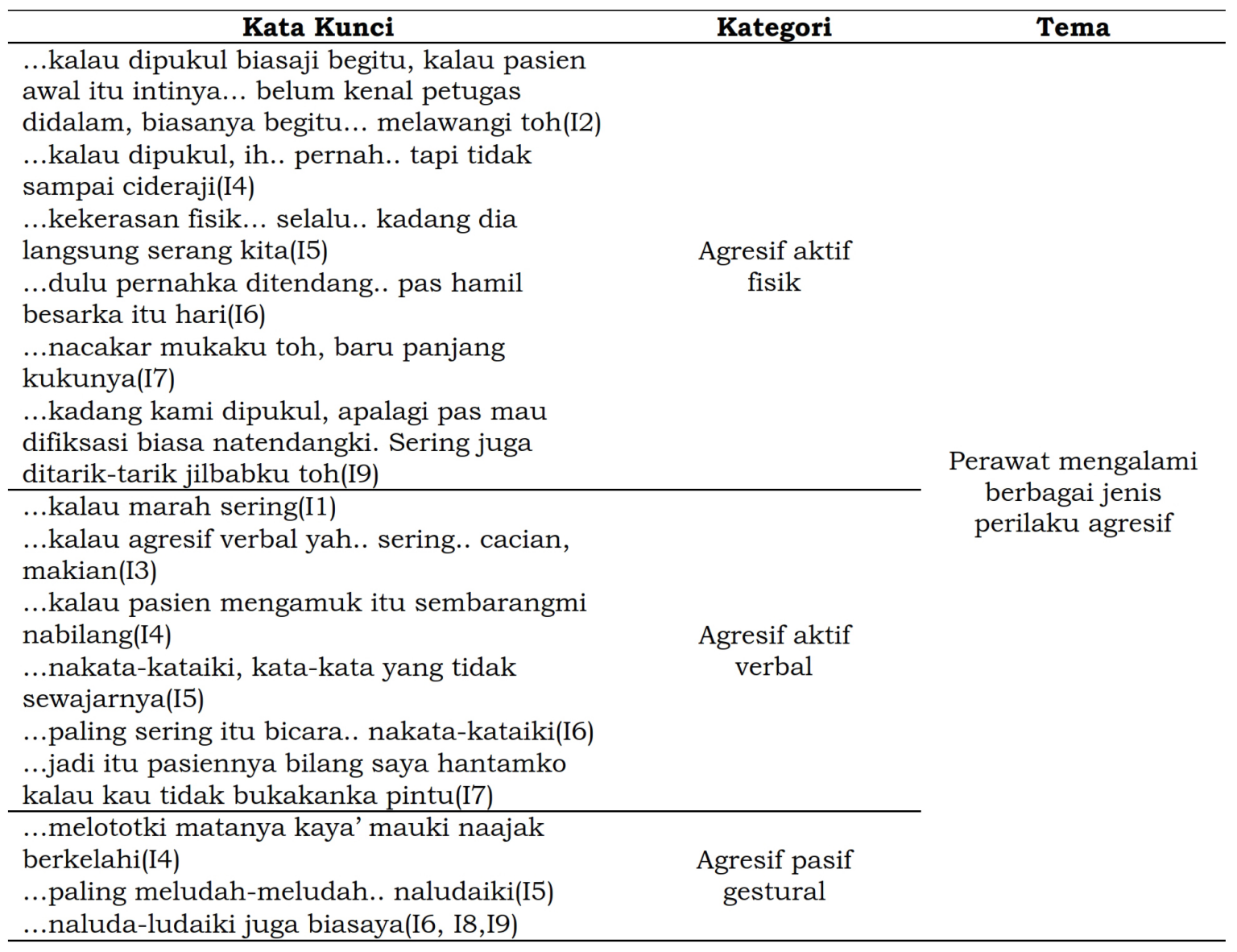

Tabel 3. Perawat mengalami berbagai jenis perilaku agresif

\begin{tabular}{|c|c|c|}
\hline Kata Kunci & Kategori & Tema \\
\hline $\begin{array}{l}\text {.... sebenarnya itu dari individunya saja, } \\
\text { lingkungannya keras, ya.. dia bisa jadi } \\
\text { keras...(I5) }\end{array}$ & Role model & \multirow{4}{*}{$\begin{array}{c}\text { Identifikasi } \\
\text { perawat tentang } \\
\text { faktor penyebab } \\
\text { pasien berperilaku } \\
\text { agresif }\end{array}$} \\
\hline $\begin{array}{l}\text {....skizofrenia itumi yang paling sering...(I1) } \\
\text {...skizofreniami itu palingan...(I3) } \\
\text {....skizofrenia.... (I4) }\end{array}$ & $\begin{array}{c}\text { Gangguan } \\
\text { neurofisiologis }\end{array}$ & \\
\hline $\begin{array}{l}\text {....ditinggal istri atau suami...(I6) } \\
\text {....ada karna pacar...karna uang...ada.. } \\
\text { yang karna ekonomi...ada yang } \\
\text { pasangannya selingkuh...ada juga karna } \\
\text { uang...malu-malu dibilangi miskin toh...(I7) } \\
\text {...Atau karna jengkel dengan keluarga } \\
\text { sehingga dia gresif...(I9) }\end{array}$ & $\begin{array}{l}\text { Faktor sosial } \\
\text { ekonomi }\end{array}$ & \\
\hline $\begin{array}{l}\text {...tapi kalau nabilang keluarganya... biasa } \\
\text { kalau disuruhmi...adami yang sinndir- } \\
\text { sindiri..misalnya enda terlalu diterimami } \\
\text { dilingkungannya, dibilangimi orang gila..(I4) } \\
\text {....obat-obatan na konsumsi...(I6) } \\
\text {....mungkin karna napza...(I8) }\end{array}$ & Faktor lingkungan & \\
\hline
\end{tabular}

Tabel 4. Identifikasi perawat tentang faktor penyebab pasien berperilaku agresif 


\begin{tabular}{|c|c|c|}
\hline Kata Kunci & Kategori & Tema \\
\hline $\begin{array}{l}\text { “...kalau bicara sembarang nabiang...(I1, I2, } \\
\text { I4) } \\
\text { “....mengancamki juga toh...entah dengan } \\
\text { ancaman apa...”(I9) }\end{array}$ & Perkataan & \multirow{5}{*}{$\begin{array}{l}\text { Tanda-tanda } \\
\text { pasien ketika } \\
\text { sedang agresif } \\
\text { menurut } \\
\text { perawat }\end{array}$} \\
\hline $\begin{array}{l}\text { "... agak besar, berteriak-teriak..."(I1) } \\
\text { “....biasanya besar suaranya toh(I2) }\end{array}$ & Nada bicara & \\
\hline $\begin{array}{l}\text { “...tingkah lakunya gelisah...”(I1, I6, I8) } \\
\text { “....kalau begitu datang kita lihat sangar } \\
\text { diliat...”(I2) } \\
\text { “...mondar-mandir pasiennya tanpa tujuan, } \\
\text { gelisah..” (I3) } \\
\text { “...tegang toh.. gelisah..."(I5) }\end{array}$ & Sikap & \\
\hline 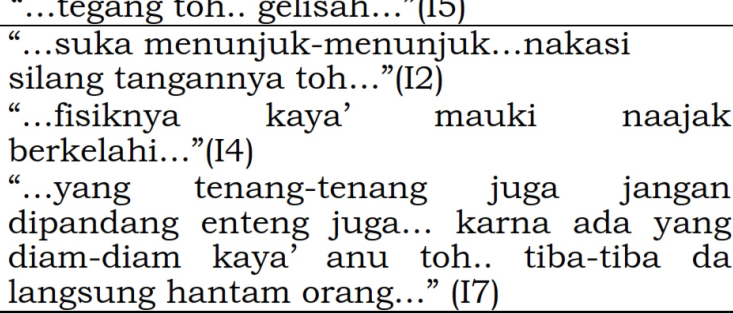 & Gestur & \\
\hline $\begin{array}{l}\text { “...matanya melotot..”(I1) } \\
\text { “...tatapan matanya...”(I3) } \\
\text { “...tatapannya itu paling pertama...kalau } \\
\text { mulaimi naliatki lain-lain...melototki } \\
\text { matanya...kaya' mauki naajak } \\
\text { berkelahi..."(I4) } \\
\text { “....matanya sering melotot, merahmi } \\
\text { matanya..."(I5, I6, I7, I8, I9) }\end{array}$ & Kontak mata & \\
\hline
\end{tabular}

Tabel 5. Tanda-tanda pasien ketika sedang agresif menurut perawat

\begin{tabular}{|c|c|c|}
\hline Kata Kunci & Kategori & Tema \\
\hline $\begin{array}{l}\text {...takut, mengerikan, mengkhawatirkan, } \\
\text { campur aduk.. ya.. biasa-biasa, kadang } \\
\text { jengkel(I3) }\end{array}$ & \multirow{2}{*}{$\begin{array}{c}\text { Dampak } \\
\text { emosional }\end{array}$} & \multirow{4}{*}{$\begin{array}{l}\text { Dampak yang } \\
\text { dirasakan perawat } \\
\text { setelah kejadian } \\
\text { agresif }\end{array}$} \\
\hline $\begin{array}{l}\text {...kadang juga marah, apalagi kalau rewelmi } \\
\text { juga anak-anak toh... kadang juga jenuh(I6) }\end{array}$ & & \\
\hline $\begin{array}{l}\text {...nacakar mukaku toh, baru panjang } \\
\text { kukunya. Sampai robek mukaku karna } \\
\text { kukunya panjangi(I7) }\end{array}$ & \multirow{2}{*}{$\begin{array}{l}\text { Cedera fisik } \\
\text { ringan }\end{array}$} & \\
\hline $\begin{array}{l}\text {...sampai pernah lebam bagian siniku.. } \\
\text { karna na tarikki baru kuat sekali caranya } \\
\text { jadi lebam-lebamki biasanya(I9) }\end{array}$ & & \\
\hline
\end{tabular}

Tabel 6. Dampak yang dirasakan perawat setelah kejadian agresif

\begin{tabular}{|c|c|c|}
\hline Kata Kunci & Kategori & Tema \\
\hline $\begin{array}{l}\text {...kalau agresif pasien, tinggalkan.. ikat(I1) } \\
\text {...yah.. langsung fiksasi(I2, I4, I6) }\end{array}$ & $\begin{array}{l}\text { Strategi } \\
\text { pembatasan } \\
\text { gerak }\end{array}$ & \\
\hline $\begin{array}{l}\text {...kita itu memberikan terapi, terus fiksasi } \\
\text { pasien(I3) } \\
\text {...ya..kita lakukan pendekatan, coba kita } \\
\text { komunikasi teraupetik, kita bicara apa yang } \\
\text { tidak pasien suka apa(I5) } \\
\text {...arahkan pendekatan secara individual } \\
\text { dulu, kalau tidak bisa biarkan...(I8) }\end{array}$ & $\begin{array}{c}\text { Strategi } \\
\text { antisipasi }\end{array}$ & $\begin{array}{c}\text { Cara perawat } \\
\text { dalam menangani } \\
\text { pasien perilaku agresif }\end{array}$ \\
\hline
\end{tabular}

Tabel 7. Cara perawat dalam menangani pasien perilaku agresif 


\begin{tabular}{|c|c|c|}
\hline Kata Kunci & Kategori & \multirow{4}{*}{$\begin{array}{l}\text { Kendala perawat dalam } \\
\text { menghadapi pasien } \\
\text { perilaku agresif }\end{array}$} \\
\hline $\begin{array}{l}\text { “...hambatannya tidak adaji, mulus-mulus } \\
\text { saja sampai sekarang karna obatnya } \\
\text { stenbay, dokternya stenbayji, pasien } \\
\text { inventaris juga siap setiap saat...”(I3) } \\
\text { “...tidak adaji. mandiri pasien toh. Mereka } \\
\text { bisa dimanfaatkan. Jadi bisa mengandalkan } \\
\text { pasien jiwa khusus, karna kita berhasilmi } \\
\text { kalau kita bisa kasi kerja orang...”(I8) }\end{array}$ & $\begin{array}{c}\text { Tidak ada } \\
\text { kendala }\end{array}$ & \\
\hline $\begin{array}{l}\text { “...kalau sehari-hari palingan kekurangan } \\
\text { tenagaji, karna masa” } 10 \text { orang perawatnya } 3 \\
\text { orang...”(I1, I9) } \\
\text { “...hambatan kayanya dari tenaga.. tenaga... } \\
\text { jadi kita butuh tenaga disini....”(I2) } \\
\text { “...disini itu palingan kekurangan } \\
\text { tenagaji...”(I4, I5, I6) }\end{array}$ & $\begin{array}{c}\text { Kekurangan } \\
\text { tenaga }\end{array}$ & \\
\hline $\begin{array}{l}\text { “...hambatannya itu pada saat awal kita mau } \\
\text { terima...pada saat dia mau masuk kita mau } \\
\text { terima toh, keluarga bawa....karna bagus- } \\
\text { bagus itu kalau kita tidak baku’ guling- } \\
\text { guling karna dia tidak merasa kalau dia } \\
\text { sakit...”(I7) }\end{array}$ & $\begin{array}{c}\text { Kendala pada } \\
\text { awal menerima } \\
\text { pasien }\end{array}$ & \\
\hline
\end{tabular}

Tabel 8. Kendala perawat dalam menghadapi pasien perilaku agresif

\section{PEMBAHASAN \\ Karakteristik Informan}

Berdasarkan hasil analisa karakteristik informan pada penelitian ini, usia responden terbanyak berada pada rentang 30-49 tahun. Menurut Sharma (2016) pada usia ini, seseorang dihadapkan pada pemenuhan tugas perkembangannya yaitu dalam hal pemenuhan tanggung jawab seperti pencapaian dan memertahankan kinerja yang memuaskan dalam pekerjaan, hal ini akan berdampak pada kehidupan seseorang apabila tidak dijalankan dengan baik.

Selanjutnya, berdasarkan hasil penelitian ini diperoleh bahwa informan dengan jenis kelamin perempuan yaitu 5 orang, dan laki-laki sebanyak 4 orang. Pendidikan terakhir dari sebagian informan dalam penelitian ini adalah diploma tiga keperawatan yaitu sebanyak 7 orang informan, 1 orang informan lulusan sarjana keperawatan ners, dan 1 orang informan lulusan sarjana kesehatan masyarakat.

\section{Perasaan perawat meghadapi pasien perilaku agresif}

Perasaan perawat menghadapi pasien perilaku agesif menghasilkan 2 kategori yaitu perasaan positif dan perasaan negatif. Perasaan positif dapat meliputi keadaan dimana seseorang merasakan hal yang biasa-biasa saja (tidak mengganggu fisik maupun mental) dan perasaan negatif (menggaggu fisik atau mental). Terdapat 5 orang informan dalam penelitian ini mengemukakan bahwa dalam menghadapi pasien perilaku agresif, perasaan yang mereka rasakan biasa-biasa saja. Perasaan tersebut disebabkan oleh pengalaman kerja informan yang sudah lebih dari 5 tahun bekerja sehingga informan telah berulang kali mengadapi pasien yang berperilaku agresif. Penelitian ini juga memperoleh hasil bahwa 7 orang informan merasakan hal negatif terkait pengalamannya dalam merawat pasien agesif seperti rasa takut, rasa khawatir, dan deg-degan. Mayoritas responden yang mengalami ketakutan berdasarkan hasil penelitian ini adalah perempuan.

Hasil penelitian ini sejalan dengan penelitian yang dilakukan oleh Lisa, Jumaini, \& Indriati (2013) yang mengemukakan bahwa reaksi negatif yang timbul adalah rasa takut dan was-was. Arnetz \& Arnetz (2010) juga membuktikan bahwa setelah kejadian tindakan agresif, perawat merasa takut pada saat bekerja. 


\section{Perawat mengalami berbagai jenis perilaku agresif}

Jenis perilaku agresif aktif verbal merupakan jenis agresif yang paling sering informan dapatkan dari hasil penelitian ini. Hal ini dibuktikan oleh pernyataan informan bahwa informan paling sering dicacimaki oleh pasien dengan menggunakan kata-kata kasar dan tidak sewajarnya, serta ancaman terhadap informan.

Jenis perilaku agresif yang sering dialami perawat menghasilkan 3 kategori antara lain jenis perilaku agresif aktif fisik, agresif aktif verbal, dan agresif pasif gestural. Terdapat 6 informan yang mengungkapkan bahwa agresif aktif fisik yang pernah mereka alami seperti pukulan, tendangan, dan cakaran. Cacian, menggunakan katakata kotor, marah terhadap perawat, dan mengancam perawat merupakan jenis agresif aktif verbal yang informan alami. Selain hal-hal tersebut, 5 informan dalam penelitian ini juga mengungkapkan bahwa pasien kadang melototi perawat dengan tatapan seperti sedang mengajak bertengkar dan informan juga sering diludahi pada saat sedang memberikan intervensi kepada pasien.

Penelitian yang dilakukan oleh Foster, Bowers, \& Nijman (2007) memperoleh hasil bahwa $60 \%$ dari kejadian agresif yang terjadi merupakan jenis agresif verbal yang sering dialami oleh kebanyakan perawat jiwa dalam satu tahun. Elita, dkk (2011) juga membuktikan bahwa 79\% kekerasan yang dilakukan pasien berupa ancaman fisik secara verbal kepada perawat.

Kurangnya perilaku agresif fisik terhadap perawat disebabkan karena perawat sudah mengetahui tandatanda ketika pasien sedang agresif sehingga perawat bisa mengantisipasi lebih awal hal-hal yang kemungkinan bisa terjadi apabila pasien sedang agresif. Oleh sebab itu, perawat hanya lebih sering mendapatkan perilaku agresif verbal dibandingkan perilaku agresif fisik.
Identifikasi perawat tentang faktor penyebab pasien berperilaku agresif

Berdasarkan hasil penelitian didapatkan 5 orang informan mengemukakan bahwa gangguan neurofisiologis seperti skizofrenia merupakan penyebab terbanyak pasien mengalami perilaku agresif.

Kesesuaian hasil penelitian ini dengan teori yang dikemukakan oleh Gabbey (2016) tentang kondisi kesehatan mental yang menyebabkan seseorang berperilaku agresif salah satunya adalah skizofrenia yang merupakan suatu penyakit yang disebabkan karena adanya kelainan pada otak yang biasanya ditandai dengan halusanasi, gangguan pikiran, dan gangguan perilaku.

Tingginya tingkat skizofrenia pada pasien gangguan mental menjadikan penyakit ini sebagai penyebab paling banyak pasien berperilaku agresif di UGD Jiwa Rumah Sakit Khusus Daerah Provinsi Sulawesi Selatan.

\section{Tanda-tanda pasien ketika sedang} agresif menurut perawat

Hasil penelitian ini diperoleh bahwa hampir semua informan setuju bahwa kontak mata sebagai tanda fisik yang informan bisa lihat ketika pasien sedang agresif adalah tatapan mata melotot, dan mata memerah.

Townsend (2012) menjelaskan bahwa mondar-mandir, gelisah, ekspresi wajah tegang dan bahasa tubuh, ancaman verbal atau fisik, suara kasar, berteriak, menggunakan kata-kata kotor menjadi tanda atau karakteristik ketika pasien sedang agresif.

Berdasarkan tanda-tanda fisik yang ditunjukkan pasien, dan masa kerja informan yang rata-rata sudah lebih dari 5 tahun bekerja membuat, informan bisa mengantisipasi lebih awal tindakan-tindakan yang akan mereka lakukan dalam menghadapi pasien perilaku agresif di UGD Jiwa Rumah Sakit Khusus Daerah Provinsi Sulawesi Selatan.

Dampak yang dirasakan perawat setelah kejadian agresif 
Dampak yang dirasakan perawat setelah kejadian agresif menghasilkan 2 kategori yaitu dampak emosional dan cedera fisik ringan. Menurut 2 orang informan dalam penelitian ini dampak yang dirasakan setelah kejadian agresif menyebabkan cedera fisik ringan seperti luka robek, dan lebam pada kulit akibat ditarik oleh pasien. 2 orang informan lain dalam penelitian ini menuturkan bahwa dampak emosional yang dirasakan seperti rasa jenuh, rasa khawatir, rasa takut, rasa jengkel, dan rasa marah. Arnetz \& Arnetz (2001) memperoleh hasil penelitian tentang dampak jangka panjang yang dialami perawat atas tindakan yang dialami adalah rasa takut pada saat bekerja. Penelitian lain yang dilakukan oleh Baby, Glue, \& Carlyle (2014) diperoleh hasil bahwa perilaku agresif ditempat kerja dapat menyebabkan dampak pada kehidupan emosional seseorang seperti ketakutan, ansietas, frustasi, stress, dan marah.

Dampak-dampak yang dirasakan oleh perawat terkait perilaku agresif pasien tidak membuat perawat mengabaikan pasien. Perawat tetap memberikan asuhan keperawatan kepada pasien perilaku agresif meskipun telah mengalami tindakan agresif dari pasien karena perawat selalu beranggapan bahwa tindakan tersebut sudah menjadi risiko dari profesi yang mereka kerjakan. Dan perawat juga sadar bahwa, yang mereka hadapi adalah orang sakit yang pikirannya sedang tergangggu sehingga tidak pernah ada keinginan untuk membalas kembali tindakan yang telah perawat alami.

\section{Cara perawat menangani pasien perilaku agresif}

Hasil penelitian yang diperoleh dari tema tersebut menghasilkan 2 kategori cara perawat menangani pasien perilaku agresif yaitu dengan cara strategi pembatasan gerak dan strategi antisipasi. Mayoritas informan dalam penelitian ini setuju untuk melakukan strategi pembatasan gerak dengan cara difiksasi (restrain/diikat) sebagai langkah awal yang dilakukan untuk menangani pasien perilaku agresif di UGD Jiwa Rumah Sakit Khusus Daerah Provinsi Sulawesi Selatan. Setelah tindakan fiksasi sudah dilakukan, maka selanjutnya perawat memberikan terapi berupa obat kepada pasien sesuai instruksi yang dituliskan oleh dokter. 3 orang informan melakukan strategi antisipasi seperti melakukan komunikasi teraupetik kepada pasien untuk menangani pasien yang sedang agresif.

Stuart (2013) menuliskan bahwa dalam menangani perilaku agresif, perawat dapat mengimplementasikan variasi intervensi seperti strategi pencegahan, strategi antisipasi, dan strategi pembatasan gerak.

Strategi pembatasan gerak dengan cara pengikatan akan berdampak pada keselamatan pasien karena meskipun metode pengikatan telah diatur dengan pengaturan tertentu, akan tetapi intervensi tersebut dapat memperburuk kondisi pasien dan menyebabkan menculnya pengalaman traumatik bagi peasien tersebut atau pasien lain yang menyaksikan hal itu (Evan, Wood, \& Lambert, 2002).

\section{Kendala perawat dalam menghadapi pasien perilaku agresif}

Hasil penelitian ini memperoleh 3 kategori yaitu yaitu tidak ada kendala, kekurangan tenaga, dan kendala pada awal menerima pasien. 2 informan dalam penelitian ini mengatakan bahwa dalam menghadapi pasien, tidak ada kendala yang dirasakan. Hal itu dikarenakan obat-obatan dan dokter selalu stand by, selain itu pasien inventaris (pasien yang diberdayakan) juga selalu membantu dalam menangani pasien perilaku agresif di UGD Jiwa Rumah Sakit Khusus Daerah Provinsi Sulawesi Selatan. Selanjutnya, 1 orang informan mengatakan bahwa kendala yang dihadapi dalam menghadapi pasien agresif adalah pada saat awal menerima pasien. Kendala yang dihadapi tersebut disebabkan oleh pasien biasanya tidak mau dimasukkan ke rumah sakit jiwa 
karena beranggapan bahwa dia tidak gila. 6 orang informan dalam penelitian ini mengeluh bahwa kendala yang mereka hadapi adalah kekurangan tenaga dalam menghadapi pasien perilaku agresif.

Kurangnya tenaga perawat dalam menghadapi pasien perilaku agresif di UGD Jiwa Rumah Sakit Khusus Daerah Sul-Sel menjadikan pasien lain (pasien inventaris) membantu perawat dalam penanganan pasien perilaku agresif (pasien baru). Selain itu, lulusan S.Kep Ners juga masih sangat kurang yang bekerja di UGD Jiwa RSKD Prov- Sul-Sel. Hal ini dibuktikan dalam penelitian ini bahwa dari 9 orang informan, hanya ada 1 orang informan yang berpendidikan terakhir strata satu keperawatan ners.

\section{KESIMPULAN}

Kesimpulan yang dapat ditarik dari penelitian ini adalah kisaran usia informan dalam penelitian ini antara 30-49 tahun dengan latar belakang pendidikan terbanyak adalah diploma tiga keperawatan. Informan telah bekerja lebih dari 5 tahun di Rumah Sakit Khusus Daerah Provinsi Sulawesi Selatan.

Dalam menghadapi pasien perilaku agresif di UGD Jiwa RSKD Prov. Sul-Sel, informan sering mengalami perilaku agresif aktif verbal seperti cacian, pasien marah kepada perawat, mengancam perawat, dan menggunakan kata-kata kasar kepada perawat. Menurut informan, skizofrenia merupakan faktor penyebab pasien berperilaku agresif. Tandatanda fisik yang bisa dilihat ketika pasien sedang agresif yaitu dari perkataan, nada bicara, sikap, gestur, dan kontak mata pasien. Dampak yang dirasakan perawat setelah kejadian agresif yang dialami membuat perawat cidera fisik ringan dan terkena dampak emosional. Cara yang paling efektif yang dilakukan perawat untuk menangani pasien perilaku agresif adalah strategi pembatasan gerak dengan cara memfiksasi (merestrein/ mengikat) pasien agar biasa dilakukan tindakan lebih lanjut. Kekurangan tenaga menjadi kendala yang dihadapi perawat dalam menghadapi pasien perilaku agresif di UGD Jiwa Rumah Sakit Khusus Daerah Provinsi Sulawesi Selatan.

\section{DAFTAR PUSTAKA}

Anderson, A., \& West, S. G. (2011). Violence Against Mental Health Professionalls: When the Treater Becoms the Victim. Innovation in Clinical Neurooscience, Vol.8 (3) , 34-39.

Arnetz, J. E., \& Arnetz, B. B. (2001). Violence towards health care staff and possible effects on the quality of patient care. Social Science and Medicine, 52 , 417-427.

Baby, M., Glue, P., \& Carlyle, D. (2014). Violence is Not Part of Our Job: A Thematic Analysis of Phychiatric Mental Health Nurses' Experiences of Patiet Assaults from a New Zealand Perspective. Issues in Mental Health Nursing, Vol.35, 647-655.

Elita, V., Setiawan, A., Wahyuni, S., \& Woferst, R. (2011). Persepsi Perawat Tentang Perilaku Kekerasan yang Dilakukan Pasien Di Ruang Rawat Inap Jiwa. Jurnal Ners Indonesia Vol.1, No.2 , 31-40.

Evan, D., Wood, J., \& Lambert, L. (2002). A review of physical restraint minimization in the acute and residential care satting. Journal of Advance Nursing, 40(6) , 616625.

Foster, C., Bowers, L., \& Nijman, H. (2007). Aggressive Behaviour on Acute Psychiatric Wards: Prevalence, Severity, and Management. Jurnal of Advanced Nursing , 140-149.

Gabbey, A. E. (2016, Maret 7). Aggressive behavior. Retrieved September 28, 2016, from healthline: http://www.healthline. com/health/aggressive-behavior

Jusmiati. (2016, Agustus 25). Pengalaman menghadapi pasien dengan perilaku agresif di rumah sakit jiwa. (Hasnah, Interviewer)

Kementerian Kesehatan Republik Indonesia. (2013). Riset Kesehatan Dasar. Retrieved September 2, 2016, from http:// www.depkes.go.id/resources/download/ general/Hasil\%20Riskesdas\%202013.pdf

Kindy, D., Petersen, S., \& Parkhurst, D. (2006). Perilous work: nurses' experinces in psychiatric nits with high risk of assault. Archives of Psychiatric Nursing, Vol.19, No.4 , 169-175.

Lisa, M., Jumaini, \& Indriati, G. (2013). Pengalaman perawat dalam merawat pasien dengan risiko perilaku kekerasan (RPK). 1-12.

National Alliance on Mental Illness. (2016). Mental Health Conditions. Retrieved 
Oktober 17, 2016, from NAMI: National Alliance on Mental Illness: https://www. nami.org/Learn-More/Mental-HealthConditions

Saryono, \& Anggraeni, M. D. (2013). Metodologi Penelitian Kualitatif dan Kuanttitatif dalam Bidang Kesehatan. Yogyakarta: Nuha Medika.

Sharma, A. (2016). Stages of Development of Psychology of People at Different Ages from Infancy to Old Age. Retrieved November 17, 2016, from Psychology Discussion: ht t p : / / w w w psychologydiscussion.net/psychology/ stages-of-development- of-psychology-of- people-at-different-ages-from-infancy-toold-age/ 732

Stuart, G. W. (2013). Principles and Practice of Psychiatric Nursing Tenth Edition. St Loius Missouri: Mosby, an imprint of Elsevier Inc.

Swan, J., \& Mitus, M. C. (2014). Workplace violence. Retrieved Agustus 24, 2016, from Wild Iris Medical Education, Inc.: http: / / nursingceu.com/courses /455/ index_nceu.html

Townsend, M. C. (2012). Psychiatric Mental Health Nursing: Concepts of Care in Evidence-Based Practice Seventh Edition. Philadelphia: F.A. Davis Company. 